\title{
Democratisation and Institutional Development in Romania after 1989
}

\section{Демократизація та інституційний розвиток в Румунії після 1989 року}

\author{
Mukesh Shankar Bharti * 1 A \\ *Corresponding author: 1 PhD in International Relations, e-mail: \\ msbharti.jnu@gmail.com, ORCID: 0000-0002-3693-7247 \\ Мукеш Шанкар Бхарті * 1 А \\ ${ }^{*}$ Corresponding author: ${ }^{1}$ Кандидат наук з міжнародних відносин, е- \\ mail: msbharti.jnu@gmail.com, ORCID: 0000-0002-3693-7247 \\ A Jawaharlal Nehru University, India
}

Received: January 27, 2022 | Revised: February 25, 2022 | Accepted: February 28, 2022

DOI: $10.33445 / s d s .2022 .12 .1 .11$

Purpose: the aim of the article is to present the institutional development and democratic setup which has been started to move forward towards economic development and the formation of welfare programmes for human development after the demise of Communist rule.

Design/Method/Approach: The article analyses how the countries had changed their policy to tie up with the European Union. Furthermore, the article discusses the Romanian politica transformation and political transitions in the country after the regime changed in late 1989 . The article asses the role of external actors to promote the establishment of democratic institutions. The case study method is driven by EU to strengthen the process of democratisation and politicalinstitutional reformation according to Copenhagen criteria.

Findings: The result of the article is that what extent the democratisation process has been successful ever inclusion to the European Union.

Paper type: theoretical.

Key words: democratisation, European Union, Romania, postcommunist, political institution, democratic transition.
Мета роботи: метою статті $€$ представлення інституційного розвитку та демократичного устрою, яке було розпочато на шляху до економічного розвитку та формування програм добробуту для людського розвитку після падіння комуністичного режиму.

Дизайн/Метод/Підхід дослідження: У статті аналізується, як країни змінили свою політику, щоб зв'язатися 3 Європейським Союзом. Крім того, у статті розглядаються румунські політичні перетворення та політичні зміни в країні після зміни режиму наприкінці 1989 року. У статті оцінюється роль зовнішніх акторів у сприянні становленню демократичних інститутів. Метод кейсового дослідження керується ЄС для посилення процесу демократизації та політико-інституційного реформування відповідно до Копенгагенських критеріїв.

Результати дослідження: Результатом статті $€$ те, наскільки успішним був процес демократизації коли-небудь включення до Європейського Союзу.

тип статті: теоретична.

Ключові слова: Демократизація, Європейський Союз, Румунія, посткомуністичний, політичний інститут, демократичний перехід.

\section{Introduction}

The fall of communism in 1989 revealed significant differences between Central and East European countries. The reforms initiated by several communist regimes during the late 1980 s smoothed the post-communist transition processes of these states. Central European countries such as Poland, Czechoslovakia and Hungary were generally more dependent on Moscow's influence than Romania. In the aftermath of the 1989 revolutions, it was hoped that democracy itself would provide the new cement for the revived polities. The expectations proved to be much too high, and although the basic mechanisms of democracy work reasonably well in this part of Europe, it would be gross exaggerations to say that post-communist societies hold together just because they were trying to become democratic. During the third wave of democratisation, the European Community (EC) played a key role in consolidating democracy in southern Europe. The EU strives to spread, strengthen and support democracy on the continent and in the world. To achieve this ambitious objective, the EU has a real toolbox to promote and implement democratic reforms. This has also occurred in Romania in the early 1990s. At the end of the 1980s, Romania was paddling against the increasingly strong reformist stream initiated in the region. Huntington (1993), described the third wave of democratisation had occurred during the 1990s. At that time in Poland, Czechoslovakia and Hungary initiatives for the development of autonomous civil society organisations gained momentum and such organisations were increasingly critical towards the communist regimes. 
Because of the third wave of democratisation Romania was also affected by this and the country smash population started the protest against the autocratic regime. The communist dictatorship exerted control over the Romanian society through several means. One of the main instruments was the Romanian Communist Party (PCR). The legacy of a patrimonial and totalitarian communist system seems to have harmed the democratisation process in Romania and the ability of elected governments to govern effectively. Due to the total lack of an active civil society and opposition during communism, the violent revolution in 1989, which led to the downfall of patrimonialtotalitarian president Ceausescu, was more or less a transfer of power among incumbent political elites, as large parts of the former nomenclature dominated the transition process and the crafting of new institutions after the fall of communism (Ciobanu, 2007).

The theoretical argument is that country-specific historical legacies from the communist period have only a secondary impact on lifting the democratic transition in the period of democratic consolidation. Since the end of the Communist regime, Romania has tried to consolidate its democracy by gaining acceptance from elites and civil society, reforming and restructuring the economy, and bringing the armed forces and intelligence agencies under democratic, civilian control. Years after the end of the Cold War, the post-Communist intelligence community-once persona non grata has, surprisingly, become one of the more trusted state institutions in Romania. Two factors can be credited with this transition of the intelligence services: an aggressive media, which helped force the government's hand at bringing about democratic reforms and an imperative for Romania to institute reforms that North Atlantic Treaty Organisation/European Union would accept to accept Romania as a full member. While formal oversight mechanisms existed, informal control, mainly through the media, has sometimes been a more effective oversight mechanism to ensure that both the popular demand for democratic norms and the Western requirements for accession have been fulfilled. The media have exposed government wrongdoing to both domestic and international audiences; thus, forcing the hand of the decision-makers to institute reforms (Ciobanu, 2007, p. 318).

\section{Review of Literature}

Alessandrini (1998) discusses the application for membership of the European Union (EU) and the adoption of an "accession partnership", with parameters and a prospective timetable, will accelerate the adaptation of the right measures to support economic and strengthen democratic institutions in Romania. The Romanian political and institutional transition can be seen as a constant struggle with its democratic political government. The revolutionary moment of 1989 was quickly followed by difficult economic reforms and disappointment with pluralist democratic politics.

The EU attaches great importance to the promotion of democracy, in particular at its external borders. The Union has bordered new strategies towards democratisation processes in its neighbourhood. Following the events of the "Arab Spring" of 2011, the EU updated its European Neighbourhood Policy (ENP) to adopt a "more for more" approach, linking support for democratic transition and "deep democracy". By establishing the criteria for EU membership in 1993, also known as the Copenhagen criteria, the democratic conditionality of formal and legal membership in the EU was realised. The imposition of legal democratic conditionality has allowed several European countries to rapidly upgrade their political systems towards democracy. Therefore, the European Union enlargement process can serve as a powerful tool to ensure democratic improvements in the pre-accession period during which the candidate countries must support their desire to join with a series of reforms that guarantee the stability of their government. and your institution. The democratic conditionality of membership involves a wide range of requirements. First of all, the stability of the government and state institutions is the main priority. The party in power must have been elected in pluralistic and open elections. The democratic nature of a political 
regime has thus become a sine qua non-condition for becoming a member of the EU. Democracy promotion is an essential and constitutive factor of the EU and is seen by many as its cornerstone. Today, the EU actively pursues this objective of democratisation in border countries and even throughout the world (European Commission, 2011).

Marginean (1997) analysing the democratisation process has progressed steadily, satisfying the formal indicators of democracy. The victory of the centre and the right-wing opposition in the November 1996 elections revealed the alternation of parties in power and thereby the consolidation of democratic institutions in Romania. Crowther (2004) analyses the post-communist political transition in Central Europe has been the subject of almost continuous debate among scholars interested in the democratisation process for the last ten years. Analysts have argued about issues such as the importance of institutional versus cultural factors, the impact of the nature of the transition, and the relative weight of internal and external variables in shaping democratisation. If anything has become clear through the accumulation of comparative research, it is that the processes involved are highly complex and that one-dimensional approaches do not provide an adequate explanation of the results. The role of European Union (EU) efforts to promote democratisation in Romania's post-communist transition. Although, the arguments that the European Union, together with other international actors, has, in fact, exerted substantial influence over the direction of Romanian domestic politics. This influence, however, must be seen as one element among many that have interacted to produce what has been a particularly troublesome path to democratic consolidation. In particular, the circumstances of the immediate postcommunist transition, the political configuration this produced, and Romania's distinctive political culture stand out as key factors in the transition process (Crowther (2004).

Cianciara (2016) discuss the term transition was used instead of transformation. Importantly, transition denotes a linear process from autocracy to democracy, while transformation is seen as more open-ended in terms of systemic outcomes. The main logic of the connection remained in line with the 2011 change: "supporting the democratic transition will contribute to the EU's own security and prosperity". The narrative continued to neglect the possibility that the process of (democratic) change could result in instability and insecurity. Interestingly, Central European leaders and analysts engaged in discussions on how to share their experience in the transition to democracy and market economy with Arab reformist movements. The normative democratic agenda has often been used by supranational European institutions (Commission, European Parliament) to strengthen their position and broaden their agenda in relation to the Member States and the Council while justifying a greater pooling of resources at the national level from the EU (Cianciara, 2015, pp. 10-11).

\section{Results and Discussion}

Institution Building after Communism. The process of institution-building in post-authoritarian Eastern Europe and Romania has predominantly proceeded in an atmosphere of uncertainty. Apart from the problems of initiating political democratisation and the absence of certain important socioeconomic prerequisites for achieving this, the unpredictability surrounding the selection of institutions has also been reinforced by the fact that this has been far from a purely rational act. The lack of information, time and willingness to compromise has prompted political leaders to act sometimes in a rush and not to select those political institutions which would best suit a country's needs in a particular moment in time or the future (Bartlett \& Hunter, 1997).

It is also necessary to keep in mind that the delayed establishment of certain political institutions and especially the adoption of constitutions have considerably reduced the chances of democracy being consolidated in some parts of the former Communist Bloc. The failure to reach an agreement between members of the democratic opposition and communist elite in certain Eastern 
European countries has left a whole range of institutional issues unresolved. This is one of the main reasons for the high vulnerability of post-communist structural arrangements and the uncertain future of reforms in other fields. The incomplete institutionalisation and half-hearted solutions proposed after each successive election have tended to keep the conflict surrounding the institutional format open. Incomplete institutional arrangements have been very difficult to improve not only because of their low legitimacy and, hence, lack of interest in their operation by the majority of the population but also because of the reduced bargaining potential of institutional creators. In such circumstances, it has been problematic to induce political actors to observe the rules of the "democratic game". It has been even less possible to get them used to them since the institutional background against which these democratic principles operate has not yet crystallised to a sufficient degree in a post-communist context (Bartlett \& Hunter, 1997, p.90)

Non-Democratic Regime. Before 1989, Romania was an authoritarian communist regime, characterised by one-party rule in the form of the Romanian Communist Party (PCR) and a cult of personality around dictator Nicolae Ceausescu and his wife Elena. Thus, in 1990 economic and social meanings associated with democracy seemed to prevail over purely political understandings of democracy, which no one believed in or supported. As in other authoritarian regimes, the country's intelligence apparatus, the Department of State Security (DSS), was the core for the regime's maintenance of political power. The DSS, better known as the Securitate was the political police of Ceausescu and his regime and he used them ruthlessly to impose his rule and coerce society. Organised in the late 1940s to defend the new regime, Securitate or "Secu" was a specially-trained force entrusted to watch over the internal security of the Ceausescu regime. Within the DSS functioned the Department of External Information (DIE), which was Romania's principal organisation focusing on foreign intelligence and counterintelligence, including technological espionage, disinformation to promote Romania's national interests and foreign policies, and monitoring the activities of exiled dissidents criticising Ceausescu's regime (Bruneau \& Boraz, 2007).

The main moments in Romania's exit from authoritarianism are linked to several key events: the breakdown of Ceausescu's dictatorship, the initial vacuum of power and the formation of the National Salvation Front (NSF) in December 1989; the growing polarization of the country's political life and the clashes between the newly formed democratic movements and parties and the NSFcontrolled government (January and February 1990); the May 1990 elections and the conflict between the Ion Iliescu-Petre Roman group, on the one hand, and the democratic forces, on the other; the violent onslaught on the new parties and civic movements in June 1990 (Bruneau \& Boraz, 2007, p.57).

Obstacles and Reforms. Backward economy, lack of honesty, isolation and moral crisis were all, in fact, different aspects of a single problem, it was believed that the country could be returned to normality simply by eliminating a few unreasonable machineries. Three things soon became more evident.

First - There was an entire social class that, having benefited from communism as the result of privileges granted (either material or psychological), was not prepared to give up the place it had occupied in society without a fight (albeit an underground one).

Secondly - Another important obstacle was the realisation that the communist regime had driven its bitterest enemies to promote an extreme approach to the fights, expressed in an unequivocal determination to replace communist totalitarianism with a system embodying its exact opposite and characterised by discipline.

Thirdly - After the initial wave of enthusiasm that clamoured for the need for reforms and changes, it was noted that from an individual point of view, such changes often ran the risk of being interpreted as a form of aggression, and reform. The principal obstacle on the road to reform is the reaction of old-style mentalities, still present not only at the decision-making level but also amongst the general population. 
Fear: present in two tenses-fear of the past and fear of the future. Although highly unlikely, the return of a communist dictatorship is still perceived as an imminent danger, causing some political forces to call for more radical measures (measures that ironically enough are often frighteningly similar to communist ideology), whose adoption may endanger the normal functioning of society. Suspicion: although in principle individuals feel safe only amid a multitude, their inner awareness clings to the idea that 'other people' are those who have hurt them in the past, are hurting them in the present and will continue to hurt them in the future. Corruption: far from being a consequence of reform (as suggested by some of the most astute enemies of change), under close examination, corruption shows clear marks of underground communism. The existence of parallel distribution networks and the confusion of rights with privileges resulting from arbitrary bureaucracy, all stem from the communist era. The new, more permissive laws have served only to increase this embedded corruption, rather than reduce it because bureaucrats at all levels continue to consider themselves above the law rather than servants to it (Szabo, 2002).

The Road to Democracy. The fall of communism in Romania coincided with the appearance of multi-party systems where independent actors had the chance to form elected governments. As the first post-communist institutional actors, the political parties grew on the crude soil of no prior competition (Mair, 1997). Pro-democracy and NSF supporters clashed between January and June 1990. The main disputes were over the NSF's refusal to call elections, finally held in May 1990. Second, the NSF's decision to participate in the elections was rejected by the rest of the political forces, as Iliescu and most of the NSF leaders were neo-communists (Kitschelt,1992). The mobilisations against the NSF were organised by the three traditional pre-communist parties and the student movement and were not repressed by the security forces (from the end of January 1990 onwards). However, they produced clashes with pro-NSF workers, mostly miners from the Jiu Valley (in June 1990). The first mobilisation pushed the NSF to share power until the elections in 1990. The second mobilisation failed in its attempt to stop the NSF from participating in the elections. Moreover, the NSF won the first free and open elections with $66 \%$ of the votes. After the miners' violent demobilisation of the students of the University of Bucharest, the student movement ended its role in the transitional period Rossi, 2012).

International Support. International support for democratisation in Romania was almost inexistent. This was a result of the lack of an organised civil society in Romania during the Ceaușescu regime. According to Chilton (1994), "Romania is the purest example of an extremely strong and repressive state apparatus and a very weak civil society (Ibid., p.25).

Intelligence in the Post-Transition Period. Romania's new government took the form of a Republic, organised under the principle of the separation and balance of powers-legislative, executive, and judicial. Political pluralism was a condition and a guarantee of the Constitution. The Constitution and the National Security Law of 1991 established oversight of all governmental activities related to national security, including intelligence and security organisations. Building new intelligence agencies and bringing them under a legal basis and democratic oversight was problematic in a country where the populace's rage at the prior intelligence apparatus was immense. As previously mentioned, during the Revolution the former Securitate was placed under the armed forces and, for a certain period, the government did not want to deal with it. However, due to several events which impacted the state's national security (ethnic unrest in two of the countries with large Hungarian minority for example), the newly-formed transitional government considered the creation of an intelligence system to be important. Establishing one service was out of the question; a return to a concentration of power was not what the Romanian people wanted after the overthrow of the communist regime. The government decided to divide the former intelligence sector into several agencies (Popa, 2007).

The Churches of Romania. The majoritarian (Romanian Orthodox) Church was co-opted by the regime and because of this, it was a passive and irrelevant actor during the transition. In 1984 
Greek Orthodox Church properties were expropriated (2500 church buildings) and all the assets were given to the Romanian Orthodox Church, which remained the only legal one and completely subordinated to the RCP (Ramet, 2004; Deletant, 2006: 82). After the fall of communism, the Church became more nationalist and started to claim more independence, but it remained compromised under the NSF and close to the state. In addition, although the Greek Church was legalised, its properties were not returned (Stan, 2010, p. 387).

The Intellectuals of the Country. According to Tismaneanu (1997), intellectual groups were among the few that promoted resistance during the Ceausescu years and organised the Group for Social Dialogue during the transition with US support. In a different interpretation, according to Siani-Davies (2005), the fact that no intellectuals were active in the resistance to the regime rendered them illegitimate as pro-democracy leaders, leaving lliescu and other former antiCeausescu RCP members as the only available leaders for the transition. Thus, there seems to have been only a small scale and isolated resistance (nationally and internationally) to the regime organised by intellectuals, and these groups were not linked to the general population (Rossi, 2012).

Student Movement. The student movement began to be mobilising during the vacuum of power and became the main mobilised actor against the (successful) attempts of the postcommunist NSF to take power. The movement was Bucharest-focused, and organised in two main social movement organisations, the Students' League (radical sector) and the Students' Union (SianiDavies, 2005, p.233). The first relevant protests by students were organised on January 29th and February 9th 1990 and called for the democratisation of the mass media, and mainly television (Siani-Davies, 2005, p. 234-235). The most relevant protest event was the occupation of the square in front of the NSF headquarters to claim for elite renewal, pushing the NSF to renounce participation in the first free and open elections. Even though Iliescu received them and discussed their claims, the NSF finally decided to participate in elections (Siani-Davies, 2005, p. 244-246). This protest was one of the main events of the cycle of mobilisations against the neo-communist elites.

Civil Society and Labour Movement. The mainstream perspective is that civil society was weak and unorganised with no international contacts during Ceausescu's regime and that it was equally irrelevant during the transition period. Although no pro-democracy movement emerged, there were important disruptive events that impacted elite attitudes. Within this context of a weak civil society, trade unions were the only actors to protest during the Ceausescu era, as already noted in previous sections. However, there is no information about waves of strikes or similar larger labour movement actions except for those already mentioned in Brasov (Siani Davies, 2005).

Following a referendum in 1991, Romania adopted a new constitution. In 1990 and 1992, Iliescu won popular elections. In the meantime, the NSF split between the more reform-oriented group headed by Petre Roman (prime minister between, 1990-1991) and Iliescu's supporters. Iliescu's Democratic Party was renamed the Party of Romanian Social Democracy (PDSR). The break between the former allies was deep and resulted in Roman's increasing rapprochement with the anti-communist coalition. Unfortunately, the 1996-2000 government was less well-prepared, both as regards the priorities of reform and the human resources necessary for implementing the changes required. The widespread growth of poverty, due mainly to delays in economic reform, caused in particular by the continuing presence of 'black holes in the national economy, quickly put paid to the possibility of maintaining the general social cohesion that was so palpable during the elections held in October 1996. Reconciliation with the past through access to old files from the 'Securitate' was enabled just after the 1996-2000 term of office. The content of the new law has upset many people in all fields and the current government has promised to restrict the activities of the institution responsible for its application. The 1996-2000 term of office contained several decisive moments for the democratic and reformist movement (Ibid., p. 67).

From the very beginning of the political transition, these two main political movements never embarked on promoting any form of pragmatic politics but instead adopted 
counterproductive and intolerant strategies. Ideological differences or debates on programmes and policies between left and right, between the former communists and the historical parties, were replaced by an ongoing inflammatory argument over the country's communist and pre-communist past. This division persisted through four elections in 1990, 1992, 1996 and 2000 and produced an endemic condition of polarised pluralism (Sartori, G. (2005). The unstable political climate that dominated the 1996-2000 period of the centre-right Democratic Convention government was a cause of serious concern within the European Union. Progress reports emphasised Romania's general lack of preparedness concerning both political and economic conditions (European Commission, 1999).

Transition to Democracy. The Democratic Institute for International Affairs (NDI) Joint International Delegation Report from the May 1990 elections concluded that the first postcommunist round of elections was "but the first step in Romania's political development". The two joint delegations which travelled to Romania in February and September 1992 felt that those elections were again tentative steps in an incomplete process. Two schools of thought emerge on Romania's progress in electoral and political reform.

1). Recent elections were a reasonably successful effort under the circumstances since the government has been preoccupied with a more immediate crisis and has not had a true opportunity to embark upon a program of fundamental political reform.

2). The government used elections for an exercise in legitimacy rather than an exercise in choice, opening the political process just enough to gain the valuable approval of western powers.

Central Election Bureau. The establishment of an effective and permanent central election authority is essential to further democratic development in Romania. At the top of an administrative hierarchy, a strong and independent central election authority with the requisite enforcement powers would serve two purposes: provide detailed interpretation of election laws and procedures and thereby impose consistency on the entire system and operate as the highest administrative body for adjudicating complaints and appeals from the local level. Gross, 2004 can be seen as a turning point in the possible consolidation of Romanian democracy, as the incumbent Socialist Party (heirs of the former communists) lost both the parliamentary and presidential elections to a more democratic, and pro-European opposition (Gross \& Tismaneanu, 2005, p. 146). The four parliamentary and presidential elections that had been held before 2004, and mostly during PSD (Socialist Party) rule, were considered as free, but not entirely fair. Party patronage, illegal use of state resources to run electoral campaigns, and unbalanced media coverage (in favour of the incumbent party) had been dominant features of Romanian politics, especially before the 2004 elections (Ciobanu, 2007). However, by 2008, both the local and parliamentary elections that were held that year were considered to be free and fair and to meet the minimum democratic requirements (Stan \& Zaharia, 2009, p. 1099).

Separation of Power. Due to the symbolic and vague nature of the constitution (of December 1991), the separation of powers is not explicit, nor are the prerogatives of various state institutions (Weber, 2002, p. 222). The Romanian constitution of 1991 allowed for a very strong presidency, where the president had the power to dissolve parliament (Weber, 2002, p. 223). The debate on whether Romania should have a more parliamentary or a more presidential system is still a 95 outstanding issue today, and is perhaps one of the main reasons why the judiciary is becoming increasingly politicised and less independent. Another important reason is the high level of competition and polarisation within the legislature, and within the executive, which makes it more difficult for the government to pass legislation. However, this also indicates that the legislature is relatively independent and able to hold the executive accountable. As a consequence of this development, an increasing number of political issues are being decided upon in the courts. Thus, the independence of the judiciary has decreased, severely weakening the ability of the judicial system to hold the executive accountable. To improve horizontal accountability, the judiciary, 
therefore, needs to be strengthened and become more independent, and the decision-making process must become more transparent and less informal, which probably requires an improved political dialogue between parties, thereby reducing the polarisation of political competition in Romania.

Rejuvenation and Accountability. Civil society experienced rejuvenation during the 2004 elections, as it played a pivotal role in mobilising the electorate, and in assuring improved vertical accountability (Gross et al., 2005, p. 148). A coalition of civil society organisations presented a proposal for a clean parliament and made successful demands that a large number of dirty politicians should be dismissed from the parliament (Gross, 2008). These civil society organisations have been highly successful in promoting higher fairness and transparency in the electoral process and in improving the accountability of the elected representatives (Ciobanu, 2007, p. 1440). This development seems to have influenced the electorate, as the relatively illiberal and semiauthoritarian rule of the PSD was punished in the 2004 elections, and they were voted out of office. However, the high level of political corruption and the informal, clientelist nature of governance has also made the Romanian electorate very disillusioned with politics and is perhaps one of the main causes behind the increased popularity of nationalistic, populist, and "anti-system» parties. Thus, the increasing activity of civil society seems to have had a countervailing effect on this trend, as its democratising influence on political elites indirectly also improves the democratic political culture among the electorate (and extremist parties have also become less prevalent since their peak in the 2000 elections).

Media Law. In May 1992, Parliament adopted an ambiguously worded Law on the Broadcasting Media which provided guidelines for establishing radio and television stations and established a new set of operational rules. However, the media law has several shortcomings which need to be addressed in additional legislation to encourage an open and diverse broadcasting industry that facilitates the unencumbered flow of information and ideas. Romania also has yet to pass any reform legislation regarding the printed press. A draft press law was introduced in Parliament but was withdrawn in the spring of 1991 after opposition members denounced it as undemocratic. A second draft law introduced in the Spring of 1992 met similar objections and has not yet been acted upon. Therefore, the press law left from the Ceausescu era theoretically remains in effect, leaving an independent press without legal guarantees and protections (Mungiu-Pippidi, 2007).

Bureaucracy and Transparency. According to Stan, the Romanian bureaucracy is inefficient, lacks transparency, and the civil servants are poorly trained and poorly paid (Stan, 2009). Over the last decade, several reforms aiming to improve the transparency and professionalism of the bureaucracy have been passed, but there is great variation in the implementation of these laws across the different ministries (Roper, 2006, p. 371). According to Roper, this is mostly due to the unequal monitoring of ministries by international agencies, such as the EU, and only those ministries that have been closely monitored and assisted by these external agencies have succeeded in establishing an adequate level of bureaucratic integrity (Roper, 2006, p. 371). In addition, the size of the staff in the bureaucracy is highly inflated, mostly due to client/patronage politics (Roper, 2006, p. 371). Romania ranked 70th in the world with a score of 3.8 out of 10 in the 2008 corruption perception index that was conducted by Transparency International.

Civil liberties. Since the fall of communism, the media have been subject to a relatively high level of party patronage, as the government is responsible for appointing officials to the broadcasting council which often refuses to grant licences to media outlets that are critical of the regime (Roper, 2006, p. 370). In addition, large sections of the media are financially indebted to (and thus dependent on) the 93 states, which could be used as leverage by the government to pressure the media into self-censorship (Roper, 2006, p. 370). 
Exit Polls and Complaint Process. The results of exit polls should not be released until after every poll has closed. This will ensure that the voting and counting processed are not compromised or influenced by the premature release of such information. The 48 hours for filing official complaints with the Central Election Bureau should be redefined and extended. All interested parties should have an opportunity to file complaints during an adequate period defined as the interval between the BEC's receipt of the results from all constituency electoral bureaus and its transmittal of those results for certification. In addition, the starting point for run-off elections should be defined as the time when results from the first round of voting are certified (Simon, 1997).

First Parliamentary Election after falling of Communism. The sixty-day electoral campaign which began in March 1990 pitted the National Salvation Front against more than 80 disparate political parties. The largest of these, the National Liberal Party and the National Peasants' Party, were the only ones to field presidential candidates against FSN leader Ion Iliescu. To some, the Front was a heroic organisation that had played a crucial role in igniting the December Revolution. To others, the Front was a manipulative band of neo-communists determined to reimpose one-party rule in Romania. The May 1990 election results gave added credence to the view that Romania remained a one-party state. The FSN won an amazing proportion of the vote in the presidential and parliamentary elections on May 20, 1990 (Simon,1997). The three presidential candidates, FSN candidate Ion Iliescu as the ostensible incumbent, received $85 \%$ of the vote, Liberal Party candidate Radu Campeanu received only $10 \%$ and a mere $3 \%$ went to Peasant Party candidate Ion Ratiu. The FSN garnered $66 \%$ and $67 \%$ of the seats in the Chamber of Deputies and Senate, respectively, which meant that Prime Minister Petre Roman also retained his position. The Hungarian Democratic Union of Romania received the second-largest bloc of votes in the parliamentary elections (7.2\%) because of their ability to dominate the vote of the Hungarian minority. The National Liberal Party polled third with $6.41 \%$, and more than 15 other parties gained parliamentary representation with less than $3 \%$ of the vote (Crowther \& Muntean, 1993).

The Central Electoral Bureau (BEC) was composed of the seven members of the constitutional court. The BEC did not believe that it was responsible for the promulgation of written guidelines for polling place administration. While BEC members would be available to any local officials who requested clarification of the electoral law, they would not assume the responsibility for the implementation of the process and its monitoring.

Modifications to the electoral law made by the Central Election Bureau (BEC) in the last fourteen days of the campaign were more cosmetic than substantive. However, the willingness of election authorities to review the process was an indication of their desire to improve Romania's electoral process. Some of the modifications included:

1) Conferences are held via telephone between the constituency election bureau chairmen, the prefects, the Central Election Bureau members, and other relevant government officials to clarify certain sections of the electoral law and eliminate confusion or misguided interpretations by local officials.

2) Election No. 27 was issued by the BEC on January 27 th which provided students with travel vouchers to return home on Election Day and vote in the districts of their legal residence.

3) An increase in civic education programs implemented by the political parties, the electronic and print media, and election authorities regarding ballot procedures and integrity.

4) Political candidates were allowed some access to military installations in the last two weeks of the campaign period to ensure that officers did not restrict information on candidates and parties available to military personnel (Carothers, 2013).

Parliamentary Elections. On November 3, 1996, a parliamentary election was held in Romania, for the third time since the December 1989 Revolution. Also, on November 3, the first round of a presidential election was held. The election was conducted under Law no. 68 of July 15, 1992, concerning the elections to the Chamber of Deputies and the Senate, published in the Official Journal no. 164 of July 
16, 1992. According to Article 1 of Law no. 68/1992, the members of the Chamber of Deputies and the Senate were elected by universal, equal, direct, secret and freely expressed ballot. The MPs and senators were elected in electoral constituencies based on party tickets and independent bids, according to the principle of proportional representation, Article 3 (1).

Accredited for the November 3, 1996 election were 13,490 domestic observers (provided by the Alliance for Peace in Romania, the Human Rights Defence League of Romania, the ProDemocracy Association, the Timisoara Society, the Romanian Association for Personal Freedom and Dignity), along with 243 international observers, including officials of the Parliamentary Assembly of the Council of Europe and the Parliamentary Assembly of the Organisation for Security and Cooperation in Europe (OSCE, 1996).

Election Results. On November 10, 1996, the Central Electoral Bureau released the list of senators and MPs after the final allocation of seats won in the November 3 parliamentary election, with the aggregate data being published in the Official Journal no. 287 of November 13, 1996. Thus, the Parliament resulting from the elections of November 3, 1996, was made up of 343 MPs (328 elected and 15 nominated by national minorities) and 143 senators. In the Senate, CDR was ranked first with 30.7 per cent of votes and 53 seats, while PDSR was ranked second, with 23.08 per cent of the votes and 41 seats. USD (PD + PDSR) received 13.16 per cent and 23 seats, while UDMR garnered 6.82 per cent and 11 seats. PNR got 4.22 per cent and 7 seats and the Greater Romania Party (PRM)4.54 per cent and eight seats. The Socialist Workers' Party (PSM) and the Agrarian Democratic Party of Romania both failed to pass the 3-per cent mark and consequently lost their Senate seats. In the Chamber of Deputies, CDR came out first, with 30.17 per cent and 122 seats, PDSR, second-with 21.52 per cent votes and 91 seats. USD (PD + RSDP) was in third place with 12.93 per cent votes and 53 seats, while the UDMR obtained 6.64 per cent and 25 seats. PRM won 19 seats ( 4.46 per cent of ballots), while PUNR won 18 seats (4.36 per cent of votes). Same as in the race for Senate, PSM failed to pass the threshold.

\section{Conclusions}

To build a new data set of political regimes and transitions during the third wave of democratisation and the 1990s, trying to address many of the measurement challenges. To do so, we use many indicators of political freedom, numerous electoral and political archives, as well as many other country-specific sources. The gap between citizens' concerns and political articulation is widened by a strong distrust of political institutions, particularly representative and pluralist ones - Parliament and political parties. General support for democracy as a regime remained strong during the transition. The main scope of democratic transition was institutional building-constitutions, rights and freedoms, parties, elections, checks and balances, it must move towards the socio-economic basis of democracy at the next level of transition. Democracy is only possible where there is a certain level of socio-economic cohesion. Moreover, since the accession to the EU, Romania doesn't accelerate human and social development which has been settled down by the European Union. Romania has been unable to fulfil the EU's expectations. Existing political parties need serious internal reform and openness to providers of ideas and energy, civil society organisations, activists, researchers, local communities. Finally, Parliament is the only higher legislative body where anybody can raise their voice, and it became a forum for democratic space and the instrument of renewed democratic control over decisions and policies. The European Union as a key promoter of democracy in the region continuously making pressure on Romania towards the settlement of democratic institutions in the country. The research further talks the possibility that the democratisation process could lead - in a given geopolitical, socioeconomic and cultural context- to instability, was absent from the story.

By analysing the major stages of the democratisation process in Romania, we note the 
significant progress made in the institutional construction and establishment of the right-wing state. This political situation can be an important support for the economic reform measures that will have to be taken in the future. The first post-communist elections in 1990 were only a first step toward Romania's political development. The conclusions of a report on Romania's process of transition in the early'90s, elaborated by the International Republican Institute (IRI) and the National Democratic Institute for International Affairs (NDI), reveal that, under the conditions of that period (early 1990 a time of increased social, political and economic instability), the elections were a laudable effort from the state institutions, even if the government was more concerned with the daily crisis than the attempt to implement a concrete program to reform the political system. The first two parliamentary elections made a way for democratisation in the country. The constitution of Romania had created a history for the restoration of democratisation norms in the country. The role of the European Union and ENP had created democratic norms across the East and Central European countries. Romania has problems in some parts of the country in the area of crime and corruption. The country is progressing in many fields but democratisation is limited in some parts of the areas. The political institutions are being formulated as fragile organisations.

\section{Funding}

This study received no specific financial support.

\section{Competing interests}

The authors declare that they have no competing interests.

\section{References}

Alessandrini S. (1998). Transition and Democracy in Romania: The Pains of a Gradualist Restructuring. In: Larçon JP. (eds) Entrepreneurship and Economic Transition in Central Europe. Springer, Boston, MA. DOI: 10.1007/978-1-4615-6401-0_8

Alvarez, M., Cheibub, J. A., Limongi, F., \& Przeworski, A. (1996). Classifying political regimes. Studies in Comparative International Development, 31(2), 3-36.

Bartlett, D., \& Hunter, W. (1997). Market structures, political institutions, and democratisation: the Latin American and East European experiences. Review of International Political Economy, 4(1), 87-126.

Bharti, S. S. (2020). Strengthening the Development Partnership between the EU and South Asia: A Contemporary Analysis. Slovenská politologická revue, 20(2), 278-298.

Bruneau, T. C., \& Boraz, S. C. (2007). Reforming Intelligence: obstacles to democratic control and effectiveness. University of Texas Press.

Carothers, T. (2013). Assessing democracy assistance: The case of Romania. Brookings Institution Press.

\section{Список використаних джерел}

Alessandrini S. (1998). Transition and Democracy in Romania: The Pains of a Gradualist Restructuring. In: Larçon JP. (eds) Entrepreneurship and Economic Transition in Central Europe. Springer, Boston, MA. DOI: 10.1007/978-1-4615-6401-0_8

Alvarez, M., Cheibub, J. A., Limongi, F., \& Przeworski, A. (1996). Classifying political regimes. Studies in Comparative International Development, 31(2), 3-36.

Bartlett, D., \& Hunter, W. (1997). Market structures, political institutions, and democratisation: the Latin American and East European experiences. Review of International Political Economy, 4(1), 87-126.

Bharti, S. S. (2020). Strengthening the Development Partnership between the EU and South Asia: A Contemporary Analysis. Slovenská politologická revue, 20(2), 278-298.

Bruneau, T. C., \& Boraz, S. C. (2007). Reforming Intelligence: obstacles to democratic control and effectiveness. University of Texas Press.

Carothers, T. (2013). Assessing democracy assistance: The case of Romania. Brookings Institution Press. 
Cianciara, A. K. (2016). Stability, security, democracy: explaining shifts in the narrative of the European Neighbourhood Policy. Journal of European Integration, 39(1), 49-62.

Ciobanu, M. (2007). Romania's travails with democracy and accession to the European Union. Europe-Asia Studies, 59(8), 14291450.

Ciobanu, M. (2009). Reconstructing the role of the working class in communist and postcommunist Romania. International Journal of Politics, Culture, and Society IJPS, 22(3), 315-335.

Crowther, W. E., \& Muntean, G. (1993). Electoral politics and transition in Romania. National Council for Soviet and East European Research.

Crowther, W. (2004). The European Union and Romania: the politics of constrained transition. In the European Union \& Democratisation (pp. 99-122). Routledge.

Dahl, R. A. (2000). A democratic paradox? Political Science Quarterly, 115(1), 35-40.

European Commission (1999). “Romania Regular Report 1999, Regular Report from The Commission on Romania's Progress Towards Accession". European Commission 1-94.

European Commission (2011). A New Response to a Changing Neighbourhood, A review of European Neighbourhood Policy, 2011. Joint Communication by the High Representative of The Union for Foreign Affairs and Security Policy and the European Commission. Available at: http://eeas.europa.eu/enp/pdf/pdf/com_1 1_303_en.pdf (accessed on January 25th 2022).

Gross, P. (2008). Forward to the Past: The intractable problems of Romania's media system. The International journal of press/politics, 13(2), 141-152.

Gross, P., \& Tismaneanu, V. (2005). The end of postcommunism in Romania. Journal of Democracy, 16(2), 146-162.

Huntington, S. P. (1993). The third wave: Democratization in the late twentieth century (Vol. 4). University of Oklahoma Press.

Kitschelt, H. (1992). The formation of party systems in East-Central Europe. Politics \& Society, 20(1), 7-50.
Cianciara, A. K. (2016). Stability, security, democracy: explaining shifts in the narrative of the European Neighbourhood Policy. Journal of European Integration, 39(1), 49-62.

Ciobanu, M. (2007). Romania's travails with democracy and accession to the European Union. Europe-Asia Studies, 59(8), 14291450.

Ciobanu, M. (2009). Reconstructing the role of the working class in communist and postcommunist Romania. International Journal of Politics, Culture, and Society IJPS, 22(3), 315-335.

Crowther, W. E., \& Muntean, G. (1993). Electoral politics and transition in Romania. National Council for Soviet and East European Research.

Crowther, W. (2004). The European Union and Romania: the politics of constrained transition. In the European Union \& Democratisation (pp. 99-122). Routledge.

Dahl, R. A. (2000). A democratic paradox? Political Science Quarterly, 115(1), 35-40.

European Commission (1999). "Romania Regular Report 1999, Regular Report from The Commission on Romania's Progress Towards Accession". European Commission 1-94.

European Commission (2011). A New Response to a Changing Neighbourhood, A review of European Neighbourhood Policy, 2011. Joint Communication by the High Representative of The Union for Foreign Affairs and Security Policy and the European Commission. Available at: http://eeas.europa.eu/enp/pdf/pdf/com_1 1_303_en.pdf (accessed on January 25th 2022).

Gross, P. (2008). Forward to the Past: The intractable problems of Romania's media system. The International journal of press/politics, 13(2), 141-152.

Gross, P., \& Tismaneanu, V. (2005). The end of postcommunism in Romania. Journal of Democracy, 16(2), 146-162.

Huntington, S. P. (1993). The third wave: Democratization in the late twentieth century (Vol. 4). University of Oklahoma Press.

Kitschelt, H. (1992). The formation of party systems in East-Central Europe. Politics \& Society, 20(1), 7-50. 
Lipset, S. M. (1959). Some social requisites of democracy: Economic development and political legitimacy. American political science review, 53(1), 69-105.

Mair, P. (1997). Party system change: approaches and interpretations. Oxford University Press.

Marginean, I. (1997). Indicators of democratization in Romania. Social indicators research, 42(3), 353-366.

Montes, J. E., Mainwaring, S., \& Ortega, E. (2000). Rethinking the Chilean party systems. Journal of Latin American Studies, 32(3), 795-824.

Mungiu-Pippidi, A. (2007). Disputed identity as unescapable pluralism. Moldova's ambiguous Transition. Romanian Journal of Political Sciences, (02), 85-102.

OSCE. 1996. "Romania, Parliamentary and Presidential Elections, 3 and 17 November 1996: Final Report." Organisation for Security and Co-Operation in Europe. Available at: https://www.osce.org/odihr/ elections/romania/16254.

Popa, R. M. (2007). State of the art and mapping of competencies report Romania.

Roper, S. D. (2006). The influence of party patronage and state finance on electoral outcomes: Evidence from Romania. Journal of Communist Studies and Transition Politics, 22(3), 362-382.

Rossi, F. M. (2012). From the Coup to The Escalation of Violence: The Transition to Democracy in Romania.

Sartori, G. (2005). Parties and party systems: A framework for analysis. ECPR Press.

Schumpeter, J. A. (1942). Capitalism, socialism and democracy. Available at: https://msuweb.montclair.edu/ lebelp/Sc humpeterChapter7.pdf (accessed on January 25th 2022).

Siani-Davies, P. (2005). The Romanian revolution of December 1989. Cornell University Press.

Simon, J. (1997). Electoral systems and democracy in central Europe, 1990-1994. International Political Science Review, 18(4), 361-379.

Stan, L. (2009). Transitional justice in Eastern Europe and the former Soviet Union: Reckoning with the communist past. Routledge.

Stan, L. (2010). Romania: In the shadow of the past. Central and Southeast European Politics since 1989, 379-400.
Lipset, S. M. (1959). Some social requisites of democracy: Economic development and political legitimacy. American political science review, 53(1), 69-105.

Mair, P. (1997). Party system change: approaches and interpretations. Oxford University Press.

Marginean, I. (1997). Indicators of democratization in Romania. Social indicators research, 42(3), 353-366.

Montes, J. E., Mainwaring, S., \& Ortega, E. (2000). Rethinking the Chilean party systems. Journal of Latin American Studies, 32(3), 795-824.

Mungiu-Pippidi, A. (2007). Disputed identity as unescapable pluralism. Moldova's ambiguous Transition. Romanian Journal of Political Sciences, (02), 85-102.

OSCE. 1996. "Romania, Parliamentary and Presidential Elections, 3 and 17 November 1996: Final Report." Organisation for Security and Co-Operation in Europe. Available at: https://www.osce.org/odihr/ elections/romania/16254.

Popa, R. M. (2007). State of the art and mapping of competencies report Romania.

Roper, S. D. (2006). The influence of party patronage and state finance on electoral outcomes: Evidence from Romania. Journal of Communist Studies and Transition Politics, 22(3), 362-382.

Rossi, F. M. (2012). From the Coup to The Escalation of Violence: The Transition to Democracy in Romania.

Sartori, G. (2005). Parties and party systems: $A$ framework for analysis. ECPR Press.

Schumpeter, J. A. (1942). Capitalism, socialism and democracy. Available at: https://msuweb.montclair.edu/ lebelp/Sc humpeterChapter7.pdf (accessed on January 25th 2022).

Siani-Davies, P. (2005). The Romanian revolution of December 1989. Cornell University Press.

Simon, J. (1997). Electoral systems and democracy in central Europe, 1990-1994. International Political Science Review, 18(4), 361-379.

Stan, L. (2009). Transitional justice in Eastern Europe and the former Soviet Union: Reckoning with the communist past. Routledge.

Stan, L. (2010). Romania: In the shadow of the past. Central and Southeast European Politics since 1989, 379-400. 
Stan, L., \& Zaharia, R. (2009). Political Data Yearbook 2008 Romania. European Journal of Political Research, 48(7-8), 1087-1099.

Szabo, K. F. (2002, October). Parliamentary Overview of Intelligence Services in Romania. In Makalah Untuk Workshop Democratic and Parliamentary Oversight of Intelligence Services, Geneva (pp. 3-5).

Weber, R. (2002). The Romanian Constitutional Court: In Search of its Own Identity. Constitutional Justice, East and West: Democratic Legitimacy and Constitutional Courts in Post-Communist Europe in a Comparative Perspective, 62, 283.
Stan, L., \& Zaharia, R. (2009). Political Data Yearbook 2008 Romania. European Journal of Political Research, 48(7-8), 1087-1099.

Szabo, K. F. (2002, October). Parliamentary Overview of Intelligence Services in Romania. In Makalah Untuk Workshop Democratic and Parliamentary Oversight of Intelligence Services, Geneva (pp. 3-5).

Weber, R. (2002). The Romanian Constitutional Court: In Search of its Own Identity. Constitutional Justice, East and West: Democratic Legitimacy and Constitutional Courts in Post-Communist Europe in a Comparative Perspective, 62, 283. 